\title{
Selenium supplementation in radiotherapy patients: do we need to measure selenium levels in serum or blood regularly prior radiotherapy?
}

\author{
Ralph Muecke ${ }^{1,2^{*}}$, Oliver Micke ${ }^{3}$, Lutz Schomburg ${ }^{4}$, Klaus Kisters $^{5}$, Jens Buentzel ${ }^{6}$, Jutta Huebner ${ }^{7}$ and Jan Kriz $^{8}$
}

\begin{abstract}
Considering the review by Puspitasari and colleagues, an additional discussion of the endpoints of the Se supplementation studies described would be helpful. In our view, selenium can safely be given to selenium-deficient cancer patients prior to and during radiotherapy. Therefore, in order to help the radiation oncologist in decision making, we strongly advocate to determine the selenium status prior to and during a potential adjuvant selenium supplementation, e.g. when trying to ease the side-effects of radiation treatment or in the aftercare situation when the selenium status may become insufficient.
\end{abstract}

Keywords: Selenium, Supplementation, Clinical studies, Selenoproteins, Radiotherapy

We have read with great interest the review of Puspitasari et al. and would like to thank the authors for this interesting summary which shows the possible benefits of selenium supplementation in radiotherapy patients reducing side effects and thus improving quality of life without compromising the effectiveness of radiotherapy [1].

In the introduction, the authors point to the necessity of a guideline helping physicians and patients with their decisions concerning selenium supplementation. They correctly point to the lack of comprehensive data. Yet, if one enlarges the range of their systematic search, there are additional data which to our opinion could form the basis of practice rules concerning selenium in cancer care. In fact, there is a wealth of preclinical and clinical data pointing to the dose-dependency of health effects from selenium supplementation and the high mortality risk of selenium-deficient cancer patients [2].

According to recently published studies it seems most important for cancer patients to achieve and maintain a certain range of Se in the serum. Nutritional Se intake, plasma Se concentration and glutathione peroxidase (GPx) activity display a positive correlation up to a

\footnotetext{
* Correspondence: ralph.muecke@klinikum-lippe.de

'Department of Radiotherapy, Lippe Hospital Lemgo, Rintelner Str. 85,

D-32657 Lemgo, Germany

${ }^{2}$ Department of Radiotherapy and Radiation Oncology, Ruhr University

Bochum, Bochum, Germany

Full list of author information is available at the end of the article
}

certain threshold plasma Se concentration $(70-100 \mu \mathrm{g} / \mathrm{L})$, beyond which the GPx activity plateaus [3]. The limit at which selenoprotein $\mathrm{P}$ (SePP) concentrations may no longer increase with higher Se intake has been determined at levels of around 90-125 $\mu \mathrm{g}$ Se/l plasma [4-6]. Consequently, the optimal Se range in serum likely resides between 100 and $130 \mu \mathrm{g} / \mathrm{l}[7,8]$. This is in accordance with epidemiological and clinical data which underline that cancer and mortality risks inversely correlate to Se concentrations at suboptimal levels $<100 \mu \mathrm{g}$ Se/l plasma as compared to higher Se status [9].

Considering the review by Puspitasari and colleagues, an additional discussion of the endpoints of the Se supplementation studies described would be helpful. In order to determine effects from selenium basic and follow-up levels need to be determined. Unfortunately, some well-known and frequently cited allegedly negative studies did not obey to these simple rules and it is thus difficult to interpret their findings $[10,11]$.

Therefore, in order to help the radiation oncologist in decision making, we strongly advocate to determine the selenium status prior to and during a potential adjuvant selenium supplementation, e.g. when trying to ease the side-effects of radiation treatment or in the aftercare situation when the selenium status may become insufficient. The potential benefits for the cancer patient under radiotherapy are well-documented and undisputed [1,2]. 
In our view, selenium can safely be given to seleniumdeficient cancer patients prior to and during radiotherapy. Considering the known uncertainties around the appropriate Se dose and Se compound we would propose the inorganic form sodium selenite without unspecific incorporation into non-selenoenzymes and daily doses higher than in the above mentioned gynecological study of $500 \mu \mathrm{g}$ since the patients with Se supplementation did not achieve Se levels in the serum higher than $75 \mu \mathrm{g} / \mathrm{l}$ [12]. Finally we want to point out that selenium is not a medication per se but rather an adjuvant treatment option supporting the biosynthesis of 25 human genes encoding the functionally active selenoproteins needed for limiting the side effect of radiation therapy and supporting a fast recovery.

\section{Competing interests}

The authors declare that they have no competing interests.

\section{Authors' contributions}

All authors participated in the drafting and revising of the manuscript. All authors read and approved the final manuscript.

\section{Authors' information}

In Regard to: Irma M Puspitasari, Rizky Abdulah, Chiho Yamazaki, Satomi Kameo, Takashi Nakano and Hiroshi Koyama: Updates on clinical studies of selenium supplementation in radiotherapy. Radiation Oncology 2014, 9:125.

\section{Author details}

${ }^{1}$ Department of Radiotherapy, Lippe Hospital Lemgo, Rintelner Str. 85, D-32657 Lemgo, Germany. ${ }^{2}$ Department of Radiotherapy and Radiation Oncology, Ruhr University Bochum, Bochum, Germany. ${ }^{3}$ Department of Radiotherapy and Radiation Oncology, Franziskus Hospital, Bielefeld,

Germany. ${ }^{4}$ Institute for Experimental Endocrinology, Charité Berlin, Germany. ${ }^{5}$ Department of Internal Medicine, St. Anna Hospital, Herne, Germany. ${ }^{6}$ Department of Otolaryngology, Südharz Hospital, Nordhausen, Germany. 'Working Group Integrative Oncology, German Cancer Society, Berlin, Germany. ${ }^{8}$ Department of Radiotherapy and Radiation Oncology, Münster University Hospital, Münster, Germany.

Received: 30 September 2014 Accepted: 4 December 2014

Published online: 16 December 2014

\section{References}

1. Puspitasari IM, Abdulah $\mathrm{R}$, Yamazaki $\mathrm{C}$, Kameo $\mathrm{S}$, Nakano $\mathrm{T}$, Koyama $\mathrm{H}$ : Updates on clinical studies of selenium supplementation in radiotherapy. Radiat Oncol 2014, 9:125.

2. Meyer HA, Endermann T, Stephan C, Stoedter M, Behrends T, Wolff I, Jung K, Schomburg L: Selenoprotein P Status Correlates to Cancer-Specific Mortality in Renal Cancer Patients. PLoS One 2012, 7:e46644.

3. Xia Y, Hill KE, Byrne DW, XU J, Burk RF: Effectiveness of selenium Supplements in a low-selenium area of China. Am J Clin Nutr 2005, 81:829-834.

4. Burk RF, Norsworthy BK, Hill KE, Motley AK, Byrne DW: Effects of chemical form of selenium on plasma biomarkers in a high-dose human supplementation trial. Cancer Epidemiol Biomarkers Prev 2006, 15:804-810

5. Persson-Moschos M, Alfthan G, Akesson B: Plasma selenoprotein P levels of healthy males in different selenium status after oral supplementation with different forms of selenium. Eur J Clin Nutr 1998, 52:363-367.

6. Hurst R, Armah CN, Dainty JR, Hart DJ, Teucher B, Goldson AJ, Broadley MR, Motley AK, Fairweather-Tait SJ: Establishing optimal selenium status: results of a randomized, double-blind, placebo-controlled trial. Am J Clin Nutr 2010, 91:923-931.

7. Muecke R, Schomburg L, Buentzel J, Kisters K, Micke O: Blood selenium Status in tumor patients: Omnia sunt venena, nihil est sine veneno. Sola dosis facit venenum. Trace Elem Electrolytes 2010, 27:181-182.
8. Muecke R, Schomburg L, Buentzel J, Kisters K, Micke O: Selenium or no selenium-that is the question in tumor patients: a new controversy. Integr Cancer Ther 2010, 9:136-141.

9. Bleys J, Navas-Acien A, Guallar E: Serum selenium levels and all cause, cancer, and cardiovascular mortality among US adults. Arch Intern Med 2008, 168:404-410.

10. Karp DD, Lee SJ, Keller SM, Wright GS, Aisner S, Belinsky SA, Johnson DH, Johnston MR, Goodman G, Clamon G, Okawara G, Marks R, Frechette E, McCaskill-Stevens W, Lippman SM, Ruckdeschel J, Khuri FR: Randomized, Double-Blind, Placebo-Controlled, Phase III Chemoprevention Trial of Selenium Supplementation in Patients With Resected Stage I Non-Small- Cell LungCancer: ECOG 5597. J Clin Oncol 2013, 31(33):4179-4187.

11. Lippman SM, Klein EA, Goodman PJ, Lucia MS, Thompson IM, Ford LG, Parnes HL, Minasian LM, Gaziano JM, Hartline JA, Parsons JK, Bearden JD, Crawford ED, Goodman GE, Claudio J, Winquist E, Cook ED, Karp DD, Walther P, Lieber MM, Kristal AR, Darke AK, Arnold KB, Ganz PA, Santella RM, Albanes D, Taylor PR, Probstfield JL, Jagpal TJ, Crowley JJ, et al: Effect of selenium and vitamin $\mathrm{E}$ on risk of prostate cancer and other cancers: The selenium and vitamin E cancer prevention trial (SELECT). JAMA 2009, 301:39-51.

12. Muecke R, Schomburg L, Glatzel M, Bernd-Skorka R, Baaske D, Reichl B, Buentzel J, Kundt G, Prott FJ, De Vries A, Stoll G, Kisters K, Bruns F, Schaefer U, Willich N, Micke O: Multicenter, phase III trial comparing selenium supplementation with observation in gynecologic radiation oncology. Int J Radiat Oncol Biol Phys 2010, 70:828-835.

doi:10.1186/s13014-014-0289-0

Cite this article as: Muecke et al:: Selenium supplementation in radiotherapy patients: do we need to measure selenium levels in serum or blood regularly prior radiotherapy? Radiation Oncology 2014 9:289.

\section{Submit your next manuscript to BioMed Central and take full advantage of:}

- Convenient online submission

- Thorough peer review

- No space constraints or color figure charges

- Immediate publication on acceptance

- Inclusion in PubMed, CAS, Scopus and Google Scholar

- Research which is freely available for redistribution 